\title{
Does Financial and Trade liberalization Drive Private Investment in Pakistan?
}

\author{
Qazi Muhammad Adnan Hye ${ }^{1}$ \\ Wee-Yeap Lau ${ }^{2}$
}

' Adjunct Faculty, Mohammad Ali Jinnah University, Karachi, Pakistan Email:adnan.econ@gmail.com Tel:+923146715528

${ }^{2}$ Faculty of Economics and Administration University of Malaya, Malaysia

Email:rovlau@um.edu.my

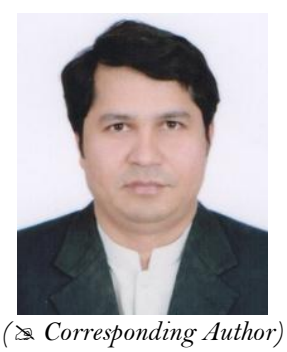

\begin{abstract}
There is evidence in economic growth literature that private investment enhances economic growth of developing countries. Recent economic growth policies in Pakistan has concentrated more on encouraging private sector investment through the liberalization of the financial and trade sectors. However, previous studies have ignored the impact of trade and financial liberalization on private investment. This study investigates the short- and long-run impact of financial and trade liberalization on private investment in Pakistan. Using the data from 19712014 on the ARDL bounds testing approach to cointegration, our result suggests that: First, per capita real private income, public investment, and financial liberalization are positively related to private investment in the long run; Second, real interest rate and trade openness are negatively related to private investment in the long run; and finally, the short-run results indicate that capital account liberalization and financial openness are positively associated with private savings.
\end{abstract}

Keywords: Financial and trade liberalization, Private savings, ARDL, Pakistan

JEL Classification: E2 1; F43; F60.

Citation | Qazi Muhammad Adnan Hye; Wee-Yeap Lau (2018). Does Financial and Trade liberalization Drive Private Investment in Pakistan? Asian Journal of Economics and Empirical Research, 5(2): 112-120.

History:

History:

Revised: 1 August 2018

Accepted: 15 August 2018

Published: 10 September 2018

Licensed: This work is licensed under a Creative Commons

Attribution 3.0 License $(\mathrm{cc})$

Publisher:Asian Online Journal Publishing Group
Contribution/Acknowledgement: Both authors contributed to the conception and design of the study.

Funding: This study received no specific financial support

Competing Interests: The authors declare that they have no conflict of interests.

interests. Transparency: The authors confirm that the manuscript is an honest,
accurate, and transparent account of the study was reported; that no vital features of the study have been omitted; and that any discrepancies from the study as planned have been explained.

Ethical: This study follows all ethical practices during writing.

\section{Contents}

1. Introduction

2. Financial and Trade Reforms

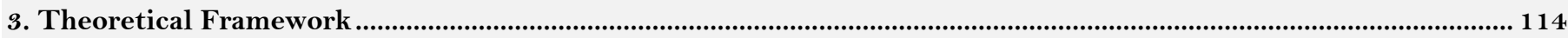

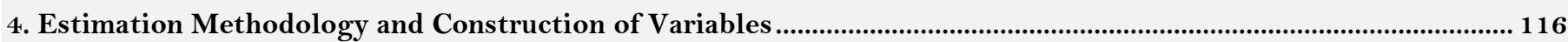

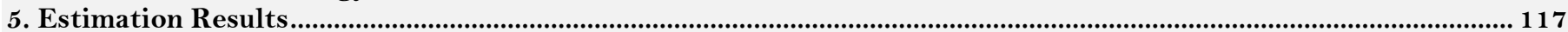

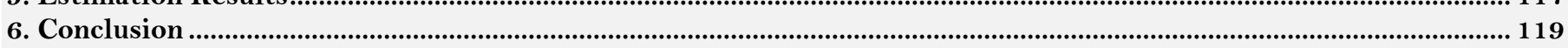

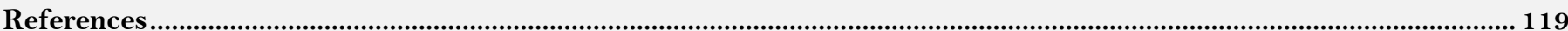




\section{Introduction}

According to the neoclassical framework of the repressed financial systems, firms do not get an unlimited supply of credit. The neoclassical framework assumes that perfectly competitive markets prevail. Stiglitz and Weiss (1981) state developing countries frequently face credit restraints due to market imperfections such as unequal information. The imperfect credit market stops firms from acquiring enough borrowing. This type of restraint generally discourages the investment activities. The study of Ang and McKibbin (2007) test the influence of financial deregulation on private investment in the case of Malaysia. They suggest that an appropriate mix of financial liberalization and repression strategies effective in stimulating private investment.

Neo-structuralist Van Wijnbergen (1982) and Taylor (1983) state that lower tax collection and higher Government borrowing can cause financial systems to reduce credit flow to the private sector. The official financial systems focus on reserve requirements that show leakage in the intermediation process. The neo-structuralists claim that unorganized markets perform more efficiently in intermediating savers and investors. Stiglitz (1994a) claims that restraint interest rate may increase savings in the financial system with the existence of good governance. He explains that depositor may observe the restriction as a strategy of stability in the financial system; the saver may be keen to keep their savings in the form of bank deposits. Thus, there is a possibility of more resources for investment in the absence of perfect capital mobility.

Razin et al. (2002) argue that openness may have non-traditional links with investment level and its cyclical behaviour. Discrete "jump" in the level of investment in the stage of trade liberalization is plausible due to a discrete change in the terms of trade which can considerably boost aggregate investment. However, trade openness could also lead to boom-bust cycles in investment or create multiple-equilibrium. Sizable gain from globalization can be accrued from investment-boom equilibrium. Conversely, benefits, if any from investment-bust equilibrium is either small or negative. Openness can disrupt an economy.

Hellmann et al. (2000) use a dynamic model to show that capital can be recycled in a prudent manner to overcome the problem of moral hazard. Through a combination of capital requirement and deposit rate controls, banks can be incentivized in a Pareto-optimal manner. The line of direct credit commonly allows controlled distribution of credit to priority areas such as agriculture and industry. They point out that without such interferences, banks normally will not supply fund to activities with low yields. ${ }^{1}$

Greene and Villanueva (1991) use 1975-87 data to examine the influence of macroeconomic variables on private investment in 23 developing countries ${ }^{2}$ and find that real growth of GDP, level of GDP per capita, and the rate of public sector investment are positively related to private investment; but real interest rates, domestic inflation, debt-service ratio, and the ratio of debt to GDP affect private investment negatively.

On the other hand, private investment expenditure is positively related to domestic credit and net capital inflow to the private sector in the developing countries (Zebib and Muoghalu, 1997). Henry (2000) includes stock market liberalization ${ }^{3}$ in a private investment model and finds that the former causes private investment booms in 11 developing countries. In the case of developing countries, ${ }^{4}$ Salahuddin et al. (2009) find a positive impact of the growth rate of per capita real GDP, domestic savings, trade openness, foreign aid, private sector credit and institutional development on private investment; but the negative effect of foreign debt servicing on private investment. However, he finds no significant effect of the inflation rate, lending rate, human capital and population growth on investment. He highlights the importance of efficient allocation of local resources; reduce reliance on foreign debt; increase trade openness, and institutional development and higher per capita real GDP growth to boost private/gross investment.

Using data from developing countries, ${ }^{5}$ Spatafora and Luca (2012) find that private capital inflows and domestic credit positively causes private investment. The global pricing of risk and domestic borrowing costs, increase through their impact on net capital inflows and domestic credit. However, neither more domestic credit nor superior institutional quality increases the degree to which capital inflows related to domestic investment. In the transitional economies, the impact of economic freedom, economic growth, savings, and financial development are positively related to private investment (Dang, 2012).

Jenkins (1998) estimates private investment for Zimbabwe, and find that the impact of gross profits is positive, but that of external debt $^{6}$ is negative on the private capital formation. Achy (2005) documents that financial development indicators and financial liberalization index are negatively related with private investment in the five MENA countries. ${ }^{7}$

Akkina and Celebi (2002) examine the impacts of financial repression and financial liberalization on private fixed investment in Turkey. They find that the financial repression and liberalization programs do not show any positive effect on private investment despite implementation of liberalization measures in 1983. Acosta and Loza (2005) examine the impact of the short and long-run factors affecting private investment in Argentina. They conclude that exchange rate and trade liberalization are determinants of short-term investment. In the long term, the capital accumulation, fiscal sustainability, financial development and credit market are important determinants of private investment. They establish the positive impact of financial liberalization on domestic savings, private

${ }^{1}$ McKinnon-Shaw thesis supports the elimination of directed credit programs that shift investment projects with possibly higher returns.

${ }^{2}$ The 23 countries are Argentina, Bolivia, Brazil, Chile, Colombia, Costa Rica, Ecuador, Guatemala, India, Kenya, the Republic of Korea, Mexico, Pakistan, Peru, the Philippines, Singapore, Sri Lanka, Thailand, Tunisia, Turkey, Uruguay, Venezuela, and Zimbabwe.

sStock market liberalization measured by dummy variable equals " 1 " for the liberalization period.

${ }^{4}$ Albania, Algeria, Bangladesh, Chad, Egypt, Ethiopia, Indonesia, Iran, Jordan, Malaysia, Mali, Mauritania, Morocco, Niger, Oman, Pakistan, Saudi Arabia,

Senegal, Syria, Tunisia, and Turkey.
${ }^{5}$ Albania, Algeria, Angola, Argentina, Armenia, Azerbaijan, Bangladesh, Belarus, Belize, Benin, Bolivia, Botswana, Brazil, Bulgaria, Burkina Faso, Burundi, ${ }^{5}$ Albania, Algeria, Angola, Argentina, Armenia, Azerbaijan, Bangladesh, Belarus, Belize, Benin, Bolivia, Botswana, Brazil, Bulgaria, Burkina Faso, Burundi,
Cambodia, Cameroon, Cape Verde, Central African Republic, Chad, Chile, China, Colombia, Comoros, Congo Dem. Rep.,CongoRep., Costa Rica, Côte d'Ivoire, Croatia, Dominica, Dominican Republic, Ecuador, Egypt, El Salvador, Eritrea, Ethiopia, Fiji, Gabon, Gambia, Georgia, Ghana, Guatemala, Guinea, GuineaBissau, Guyana, Haiti, Jamaica, Honduras, India, Indonesia, Iran, Jordan, Kazakhstan, Kenya, Kyrgyz, Republic, Lao PDR, Latvia, Moldova, Lebanon, Lesotho, Macedonia, Madagascar, Malawi, Malaysia, Mali, Mozambique, Mauritania, Mauritius, Mexico, Morocco, Nepal, Nicaragua, Niger, Nigeria, Pakistan Panama, Papua New Guinea, Paraguay, Peru, Philippines, Poland, Romania, Russian Federation, Rwanda, Senegal, Seychelles, Sierra Leone, South Africa, Sri Lanka, St. Lucia, St. Vincent and the Grenadines, Sudan, Swaziland, Syrian Arab Republic, Tanzania, Thailand, Togo, Tunisia, Turkey, Uganda, Ukraine, Uruguay, Uzbekistan, Vanuatu Venezuela, Vietnam, Yemen Zambia, Zimbabwe.

${ }_{6}$ increase in external debt enhances uncertainty, so negative impact on private investment.

${ }^{7}$ List of countries i.e. Egypt, Jordan, Morocco, Tunisia, and Turkey. 
investment and per capita GDP growth and negative impact on public investment. Their results indicate that financial liberalization substituting from public to private investment, which can enhance economic growth.

The positive interest rate helpful for generating higher savings and investment in Nepal (Shrestha and Chowdhury, 2007). Moreover, in the case of Thailand, Jongwanich and Kohpaiboon (2008) conclude that in the short run output growth, real private credit, and the existences of spare capacity are the main determinants of private investment. In addition, in the long run, output growth, real exchange rate (RER) and investment costs determine private investment. The export-led growth phenomenon shows the positive and statistically significant coefficient of RER. The government investment also can endorse long-term private investment, but its influences are comparatively lower than other variables.

In the case of India and Malaysia, Ang (2009) shows that credit control policy negatively causes private capital formation in both countries. The interest rate control positively impacts on private investment in both countries. However, high reserve and liquidity requirements negatively affect private investment in India, and positively in Malaysia. Spatafora and Luca (2012) examine the effect of trade liberalization on private investment in Fiji. They conclude a positive association between the two.

There are a few studies on investment in Pakistan. For example, Sakr (1993) shows that private investment positively correlates with GDP growth; credit extended to the private sector, and government investment. The private sector output, net capital inflows into the private sector, the total sources of funds, change in bank credit and past capital stock is positively linked with private investment rates in Pakistan (Majeed and Khan, 2008). Moreover, the indirect tax, debt servicing and interest rate are negatively linked with private investment. Also, the GDP, domestic savings, subsidies, and government development expenditures (PSDP) are positively related to private investment (Haroon and Nasr, 2011).

Saghir and Khan (2012) examine the determinants of public and private investment. They find that government investment negatively affects private investment, but aid positively relates to government investment in the long run.

In the case of Pakistan, several studies have estimated the private investment function. But they have ignored to check the impact of trade and financial liberalization on Private investment. This study uses the renowned databases of trade and financial liberalization such as Abiad et al. (2010) ${ }^{8}$, Chinn and Ito (2006) ${ }^{9}$, Lane and MilesiFerretti $(2007)^{10}$, and Wacziarg and Welch (2008) ${ }^{11}$ in order to estimate the private investment model by using the ARDL approach to cointegration.

The rest of the study is structured as follows. Section 2 represents the financial and trade reforms. Section 3 represents the theoretical framework. Section 4 describes estimation methodology and construction of variables. Sections 5 report the empirical results, and the last section concludes the study.

\section{Financial and Trade Reforms}

In order to increase the efficiency of the market, financial and trade liberalization was started in the late 1980's by Pakistan policymakers. The privatization of national bank was introduced to improve the efficiency of the banking sector. The interest rate was liberalized by removing limits on maximum lending rates of banks and NBFIs ${ }^{12}$ in March 1995. As part of liberalization of the financial sector in 1991, the Pak Rupee (currency) was made convertible in July 1994 under the IMF Article VIII.

The stock market plays an important role in resource allocation and providing investment opportunities. Of the three stock exchanges in Pakistan (Karachi, Lahore, and Islamabad), Karachi Stock Exchange (KSE), of which was established in 1947, dominates all others. The Lahore Stock Exchange (LSE) and the Islamabad Stock Exchange (ISE) were set up in 1974 and 1997 respectively.

In trade reforms, the tariff rate was reduced and restrictions on imports of non-capital good removed. The maximum tariff rate on imports levied was $25 \%$ in 2005 . Import substitution strategies, shaped previously, had an anti-export bias in the allocation of resources which added to inefficiency. So, import substitution was exchanged by export promotion.

In order to invite foreign direct investment, if not all, most economic sectors were opened for $100 \%$ foreign ownership. The key objective of the reforms was to attain self-reliance, build up the industrial base, root out inefficiency, improve the exports and reduce the trade deficit.

\section{Theoretical Framework}

The dynamics of private investment are based on the neo-classical model of Jorgenson (1967). We consider essential features of developing countries. In the neoclassical investment model, firms' maximize the utility of a consumption stream emphasizing on the production function which connects the flow of output to the flow of labour and capital services (Jorgenson, 1967). Through the acquisition of investment goods, firms supply capital services. The capital demand is consequently a derived demand. In the Cobb-Douglas production function (Equation 3.1) the anticipated capital stock can be positively related to output planned/level of production $\left(\mathrm{Y}^{\mathrm{e}}\right)$ and negatively to the anticipated rental cost of capital $(\mathrm{C})$ as follows:

$$
\mathrm{K}=\alpha \mathrm{Y}_{\mathrm{t}}^{\mathrm{e}} \mathrm{C}_{\mathrm{t}}^{-1}
$$

Where $\alpha$ is the distribution parameter. There are three components that determine the cost of capital, (Equation 3.1). They are the interest rate, the firm's receive opportunity cost if it traded the capital goods, and capitalized the earnings $\mathrm{RPk}_{\mathrm{t}} ; \mathrm{r}$ and $\mathrm{Pk}_{\mathrm{t}}$ respectively indicate the nominal bank lending rate and the price of capital

${ }^{8}$ Database of financial reforms.

${ }^{9}$ De jure indicator of capital account liberalization.

${ }^{10} \mathrm{De}$ facto indicator of capital account liberalization.

${ }^{11}$ De jure indicator of trade liberalization in the studies.

${ }^{12}$ For trade-related mode of financing. 
goods. The depreciation of the capital goods is the second component, which is measured by $\delta \mathrm{Pk}_{\mathrm{t}}$ where $\delta$ is the rate of depreciation. The gain/loss from anticipated deviations in the price of capital is given by:

$$
\Delta \mathrm{Pk}_{\mathrm{t}}=\pi_{\mathrm{t}}^{\mathrm{e}} \mathrm{Pk}_{\mathrm{t}}
$$

Where $\pi_{t}^{\mathrm{e}}$ is the anticipated fluctuation in the price of capital goods. These terms are deflated by general price (P) level in order to convert in real terms.

$$
\mathrm{C}_{\mathrm{t}}=\mathrm{Pk}_{\mathrm{t}} \frac{\left(\mathrm{r}+\delta+\pi_{\mathrm{t}}^{\mathrm{e}}\right)}{\mathrm{P}}
$$

In Equation 3.3 the gross private investment is represented by:

$$
\mathrm{I}_{\mathrm{i}, \mathrm{t}}=\Delta \mathrm{K}_{\mathrm{i}, \mathrm{t}}+\delta \mathrm{K}_{\mathrm{i}, \mathrm{t}-1}
$$

Equation 3.3 indicates that the gross private investment is the collection of net and replacement components. The actual capital stock does reach the anticipated level in the short term. Thus, Equation (3.3) is a function of lagged investment and adjustment coefficient as in Equation (3.4).

$$
\mathrm{I}_{\mathrm{i}, \mathrm{t}}=[1-(1-\delta) \mathrm{L}] \beta \mathrm{K}_{\mathrm{i}, \mathrm{t}}^{*}+(1-\beta) \mathrm{I}_{\mathrm{i}, \mathrm{t}-1}
$$

In Equation 3.4 $\beta$ represents the adjustment coefficient, and $L$ refers to the lag operator, (e.g. $L_{\mathrm{i}, \mathrm{t}}^{*}=\mathrm{K}_{\mathrm{i}, \mathrm{t}-1}^{*}$ ).

In the long run, firms invest to get their anticipated capital stock to the anticipated investment, as specified by a distributed lag of the changes in desired capital stock as follows:

$$
\mathrm{I}_{\mathrm{t}}=\sum_{\mathrm{j}=0}^{\mathrm{J}} \beta_{\mathrm{j}} \Delta \mathrm{K}_{\mathrm{t}-\mathrm{J}}^{*}
$$

Substituting the desired capital stock from Equation (3.1) into Equation (3.5) we find that private investment is a function of the cost of capital, output, and adjustment coefficient;

$$
\mathrm{I}_{\mathrm{t}}=\sum_{\mathrm{j}=0}^{\mathrm{J}} \beta_{\mathrm{j}} \Delta\left(\alpha \mathrm{Y}_{\mathrm{t}-\mathrm{J}}^{\mathrm{e}} \mathrm{C}_{\mathrm{t}-\mathrm{j}}^{-1}\right)
$$

According to theoretical literature, $\beta_{\mathrm{j}}$ is generally a function of economic aspects that influence the capacity of private stockholders to attain the anticipated level of investment.

Jorgenson investment model considers a perfect financial market where an unrestricted supply of capital available for firms. Under this outline, the capital user cost is a vital determinant of private investment. Within this context, attention has usually been focused on the implication of investment tax credit and depreciation rules on the cost of capital.

On the other hand, the firms unable to access an unlimited supply of credit in financially repressed systems, while the neoclassical model assumes a competitive market. Stiglitz and Weiss (1981) point to the credit restraints due to market imperfection such as asymmetric information and agency problems in developing countries. Thus, credit restraints discourage investment projects, in general.

In the seminal work on financial liberalization, Mckinnon (1973) and Shaw (1973) explain the problem of financial repression in the developing countries and offer a new model in the policy of financial liberalization. They define that financial repression policies were the main reason of low investment and poor economic performance of developing countries in the 1960s. In the controlled financial market, the funds can be allocated based on the willingness of policymakers, so both quantitative and qualitative investment suffered. Their theories suggest that loan issued at an artificially low-interest rate, directed credit programs, and high reserve requirements are major distortions in the financial systems. These can be prevented by efficient resource allocation via the reduction in savings and capital accumulation. Consequently, they support financial liberalization policies, which is referred to as the process of elimination of financial repression in order to motivate private investment and economic growth.

In contrast, the neo-structuralists suggest that it is not necessary for financial liberalization to lead investment because the formal financial systems are subject to reserve requirements, which contain a leakage in the intermediation process, the neo-structuralists claim that unorganized markets do better in intermediating process between savers and investors Van Wijnbergen (1982) and Taylor (1983). The control on interest rate may increase savings in the existence of supremacy of financial systems (Stiglitz, 1994b).

The neo-structuralists agree with McKinnon-Shaw school of thought on the reserve requirement because it may cause leakage in the intermediation process (Fry, 1988). On the other hand, Courakis (1984) shows that higher reserve requirements increase deposit rate and thus the size of loanable funds, under the assumption that the demand for loanable funds is not perfectly inelastic. Schwarz (1992) argues that directed credit programs boost investment in the targeted sectors and thus adds to gains.

Furthermore, the financial openness may assist the domestic financial system, thus there will be a more efficient allocation of capital, more investment and higher economic growth in the country (Levine, 2001).

Lahiri (2001) argues that capital mobility can be destabilizing in the sense that it increases the chance of multiple equilibria. Bhagwati (1998); Rodrik (1998) and Stiglitz (2000) show that financial openness is not necessarily welfare augmenting in the presence of distortions such as trade barriers, weak institutions, macroeconomic imbalances or information asymmetries. Thus, it appears that the impact of financial sector policies on private investment is theoretically ambiguous.

Baldwin (1989) explores the effect of trade policy on capital accumulation (human, knowledge, and physical). He suggests that medium-run growth or accumulation works through savings and investment. Trade liberalization increases the efficiency of resource allocation; and the possibility of consumption and investment in the static model (Francois et al., 1999). Trade liberalization is vital for increased productivity, employment creation, and wages as they relate to the higher level of private investment (Krueger, 1978). 
In the developing countries, public investment can complement private investment by collaborating in the area of infrastructure (Sundararajan and Thakur, 1980). Higher productivity of capital increases the overall resource availability by stimulating output. Contrariwise, public investment can crowd out private investment if the public sector directly competes with the private sector in the production of goods (Blejer and Khan, 1984).

In line with the above theoretical discussion, we propose the following general form of an empirical model of long-run private investment function:

The estimable function is as follows:

$$
I_{t}=f(P P I, R I R, P I, L I)
$$

$$
\operatorname{Ln}(\mathrm{I})=\alpha_{0}+\alpha_{1} \operatorname{Ln}(\mathrm{PPI})+\alpha_{2}(\mathrm{RIR})+\alpha_{3} \operatorname{Ln}(\mathrm{PI})+\alpha_{4} \operatorname{Ln}(\mathrm{LI})+v_{\mathrm{i}}
$$

Where Ln refers to natural logarithm and $\alpha$ represent the coefficient of respective variables to be estimated. The I, PPI, RIR, PI, and LI respectively, represent a real private investment, per capita real private income, real interest rate (user cost of capital), real private investment, and liberalization indicators (i.e. financial liberalization index, capital account liberalization index, financial openness and trade liberalization indicators). The $v_{\mathrm{i}}$ refers to the error term.

\section{Estimation Methodology and Construction of Variables}

This study employs the Augmented Dickey-Fuller (ADF) unit root test to determine the level of stationary because if the regressions run on non-stationary time series, they will produce the spurious result. The ADF unit root test is constructed on the following regression.

$$
\Delta Z_{t}=\beta_{0} z_{t-1}+\mathrm{x}_{\mathrm{t}}^{\prime} \delta+\beta_{1} z_{t-1}+\beta_{2} z_{t-2}+\ldots \ldots \ldots+\beta_{\rho} z_{t-p}+\lambda_{t}
$$

Where $Z_{t}$ refers a time series, $\Delta$ represents the first difference operator, $\mathrm{x}_{\mathrm{t}}^{\prime}$ consists of an optional exogenous variable, $\lambda_{t}$ shows a pure white noise error term, $\beta$ and $\delta$ show the estimated parameters. The unit root null hypothesis is that $\beta=0$ and alongside the alternative hypothesis $\beta<1$ using the orthodox test. The null hypothesis of a unit root does not follow the conventional student's t-distribution (Dickey and Fuller, 1979). According to different test and sample sizes, they have developed asymptotic outcomes and simulate the critical level. Further, MacKinnon (1996) develops a larger set of simulations than those tabulated by Dickey and Fuller. This study employs the MacKinnon (1996) critical value to determine the level of integration order by applying $\mathrm{ADF}$.

\subsection{ARDL Co-Integration Approach}

Many co-integration methods are available in the empirical literature. Starting from the classical approach to residual based co-integration tests of Engle and Granger (1987) multivariate tests of Johansen (1991; 1995); Banerjee et al. (1998) ECM test, among others. In current empirical investigations, the autoregressive distributed lag (ARDL) approaches to co-integration is widely used. Because it is preferable to use when variables are integrated at the different order, I(O), I(1) or combination of the both (Pesaran et al., 2001).

The ARDL approach to co-integration is based on assessing a simple Unrestricted Error-Correction Model (UECM) which can be expressed as follows: I is a dependent variable, and PPI, RIR, PI \& LI ${ }^{13}$ are the independent variables.

$$
\begin{aligned}
& \Delta L n(I)_{t}=\beta_{0}+\beta_{1} \sum_{j=1}^{k} \Delta \operatorname{Ln}(I)_{t-j}+\beta_{2} \sum_{j=0}^{k} \Delta L n(P P I)_{t-j}+\beta_{3} \sum_{j=o}^{k} \Delta R I R_{t-j}+ \\
& \beta_{4} \sum_{j=0}^{k} \Delta L n(P I)_{t-j}+\beta_{5} \sum_{j=0}^{k} \Delta \operatorname{Ln}(L I)_{t-j}++\varpi_{1} L n I_{t-1}+\varpi_{2} L n P P I_{t-1} \\
& +\varpi_{3}(R I R)_{t-1}+\varpi_{4} L n P I_{t-1}+\varpi_{5} L n L I_{t-1}+\mu_{1 t}
\end{aligned}
$$

In the Equation, 4.2 summation signs indicate the error correction dynamic whereas the term with $\varpi s$ shows the long run association. The long-run relationship test by using the F-test. The Narayan (2005) critical values are used to determine cointegration through F-test. The null hypothesis of no co-integration $\left\langle H_{0}: \varpi_{1}=\varpi_{2}=\varpi_{3}=\varpi_{4}=\varpi_{5}=0\right\rangle$ is tested against the alternate of co-integration $\left\langle H_{0}: \varpi_{1} \neq \varpi_{2} \neq \varpi_{3} \neq \varpi_{4} \neq \varpi_{5} \neq 0\right\rangle$. If the calculated F-statistic exceeds the upper bound critical value, we formerly conclude the co-integration among the variables and the null hypothesis is rejected. The t-statistic is tested through $\varpi_{1}=0$ in Eq. 3.2.

The following long-run model is estimated, after the existence of the co-integration relationship.

$$
\begin{aligned}
& \operatorname{Ln}(I)_{t}=\beta_{0}+\sum_{j=1}^{\rho} \beta_{1 j} \operatorname{Ln}(I)_{t-j}+\sum_{j=0}^{\rho} \beta_{2 j} \operatorname{Ln}(P P I)_{t-j}+\sum_{j=0}^{\rho} \beta_{3 j}(R I R)_{t=j} \\
& +\sum_{j=0}^{\rho} \beta_{4 j} \operatorname{Ln}(P I)_{t-j}+\sum_{j=0}^{\rho} \beta_{5 j} \operatorname{Ln}(L I)_{t-j}+\eta_{t}
\end{aligned}
$$

${ }^{13}$ The LI indicate the trade and financial liberation indicators. 
The Schwarz Bayesian Criterion (SBC) is used to determine the long run relationship. In the following way, error correction model (ECM) is derived from the ARDL.

$$
\begin{aligned}
& \Delta \operatorname{Ln}(I)_{t}=\beta_{0}+\sum_{j=1}^{\rho} \beta_{1 j} \Delta \operatorname{Ln}(I)_{t-j}+\sum_{j=0}^{\rho} \beta_{2 j} \Delta \operatorname{Ln}(P P I)_{t-j} \\
& +\sum_{j=0}^{\rho} \beta_{3 j} \Delta(R I R)_{t-j}+\sum_{j=0}^{\rho} \beta_{4 j} \Delta \operatorname{Ln}(P I)_{t-j}+\sum_{j=0}^{\rho} \beta_{5 j} \Delta \operatorname{Ln}(L I)_{t-j} \\
& +\lambda E C M_{t-1}+v_{t}
\end{aligned}
$$

Where $E C M_{t-1}$ is the error correction term, estimated as

$$
\begin{aligned}
& E C M_{t}=\operatorname{Ln}(I)_{t}-\beta_{0}-\sum_{j=1}^{\rho} \beta_{1 j} \operatorname{Ln}(I)_{t-j}- \\
& -\sum_{j=0}^{\rho} \beta_{2 j} \operatorname{Ln}(P P I)_{t-j}-\sum_{j=0}^{\rho} \beta_{3 j}(R I R)_{t-j}-\sum_{j=0}^{\rho} \beta_{4 j} \operatorname{Ln}(P I)_{t-j}-\sum_{j=0}^{\rho} \beta_{5 j} \operatorname{Ln}(L I)_{t-j}
\end{aligned}
$$

In Equation 4.3 the coefficients represent the short-run dynamics of the model and $\lambda$ indicating the speed of adjustment from short-run disequilibrium to long-run equilibrium.

\subsection{The Data Sources and the Definition of Variables}

This study uses annual time series from1971-2014. The data is taken from World Development Indicators (URL: http://data.worldbank.org/), State Bank of Pakistan and Pakistan Economic Survey.

\subsection{Investment}

The real private investment and real public investment are in millions of US $\$$. The real GDP, in constant prices, is taken from WDI, while the other savings and investment variables are from State Bank of Pakistan. These variables are in nominal terms and are adjusted by the GDP deflator.

\subsection{Real Interest Rate}

The real interest rate (RIR) is the user cost of capital and lending interest rate adjusted for inflation (as used by the GDP deflator).

\subsection{Financial Indicators}

The capital account liberalization index is taken from the Chinn and Ito, available at URL: http://web.pdx.edu/ ito/Chinn-Ito_website.htm. The de facto indicator of financial openness uses a total stock of assets and liabilities as constructed by Lane and Milesi-Ferretti (2007). The financial liberalization index used is developed by Hye and Lau (2017).

\subsection{Trade Indicators}

To identify the trade liberalization date (de jure), we apply the procedure by Wacziarg and Welch (2008) and the trade openness variable is constructed by taking the ratio of export plus import to GDP.

\subsection{Private Income}

We add private consumption and private saving to find aggregate private income and then adjusted by the GDP deflator. To obtain the real per capita private income, it is divided by population.

\begin{tabular}{|c|c|c|}
\hline Variables & Level & $1^{\text {st }}$ Difference \\
\hline $\operatorname{Ln}(I)$ & -2.416 & $-5.492^{a}$ \\
\hline $\operatorname{Ln}(P P I)$ & 1.366 & $-5.258^{a}$ \\
\hline RIR & -0.987 & $-12.415^{a}$ \\
\hline $\operatorname{Ln}(P I)$ & -2.416 & $-5.492^{a}$ \\
\hline Ln(K_Open $)$ & $-8.837^{a}$ & - \\
\hline $\mathrm{Ln}(\mathrm{FO})$ & -2.291 & $-5.385^{a}$ \\
\hline $\operatorname{Ln}(T O)$ & -1.697 & $-4.315^{a}$ \\
\hline $\operatorname{Ln}(F L I)$ & -2.697 & $-5.308^{a}$ \\
\hline
\end{tabular}

\section{Estimation Results}

Table-5.1 shows the ADF unit root test results. The results indicate that all variables are integrated order one expect the capital account liberalization.

Table-5.1. ADF Unit Root Test Results

Note: Ln shows the sign of natural logarithm, I to real private investment PPI stands for per capita real private income, RIR stands for real interest rate, PI stands for real public investment (PI), FLI stands for financial liberalization index, TLI stands for trade liberalization index, K_Open stands for capital account liberalization index, FO stands for financial openness index, TO stands for trade openness (TO).

a; indicate $1 \%$ level of significance.

b indicates a $5 \%$ level of significance.

c indicates a $10 \%$ level of significance. 
Table-5.2. Critical Values for ARDL Modeling Approach

\begin{tabular}{|c|c|c|c|c|c|c|}
\hline \multirow[t]{2}{*}{$K=4$} & \multicolumn{2}{|l|}{0.10} & \multicolumn{2}{|l|}{0.05} & \multicolumn{2}{|l|}{0.01} \\
\hline & $\mathrm{I}(\mathrm{O})$ & $\mathrm{I}(1)$ & $\mathrm{I}(0)$ & $\mathrm{I}(1)$ & $\mathrm{I}(0)$ & $\mathrm{I}(1)$ \\
\hline$F_{V}$ & 3.298 & 4.378 & 3.980 & 5.104 & 5.224 & 6.696 \\
\hline $\mathrm{F}_{I I I}$ & 2.638 & 3.772 & 3.178 & 4.450 & 4.394 & 5.914 \\
\hline $\mathrm{t}_{V}$ & -3.13 & -4.04 & -3.41 & -4.36 & -3.96 & -4.96 \\
\hline$t_{I I I}$ & -2.57 & -3.66 & -2.86 & -3.99 & -3.43 & -4.60 \\
\hline
\end{tabular}

Notes: $\mathrm{k}$ is the number of regressors, $F_{V}$ represents the F-statistic of the model with unrestricted intercept and trend,

$F_{I I I}$ represents the $\mathrm{F}$-statistic of the model with unrestricted intercept and no trend. $t_{V}$ and $t_{I I I}$ are the $\mathrm{t}$ ratios for

testing $\varpi_{1}$ in Equation (4.2) is respectively with and without deterministic linear trend.

Source: Narayan (2005) for F-statistics and Pesaran et al. (2001) for t-statistic.

Table-5.3. ARDL Co-integration Analysis of Private Investment Model

\begin{tabular}{|c|c|c|c|c|c|}
\hline Models & Without & terministic Trends & With D & rministic Trends & Conclusion \\
\hline & $\mathrm{F}_{\text {III }}$ & $\mathrm{t}_{\text {III }}$ & $\overline{F_{V}}$ & $\mathrm{t}_{\mathrm{V}}$ & $\overline{\mathrm{H}_{\mathrm{O}}}$ \\
\hline Model - 1: (I, PPI RIR, PI, FLI) & $4.636^{\mathrm{a}}$ & $-4.676^{\mathrm{a}}$ & $4.504^{\mathrm{a}}$ & $-4.397^{\mathrm{a}}$ & Rejected \\
\hline Model - 2: (I, PPI RIR, PI, TLI) & $3.127^{\mathrm{c}}$ & $-3.856^{\mathrm{a}}$ & $4.158^{\mathrm{b}}$ & $-4.649^{a}$ & Rejected \\
\hline Model - 3: (I, PPI RIR, PI, K_Open) & $4.649^{\mathrm{a}}$ & $-2.903^{b}$ & $4.597^{\mathrm{a}}$ & $-3.638^{b}$ & Rejected \\
\hline Model - 4: (I, PPI, RIR, PI, FOI) & $5.648^{\mathrm{a}}$ & $-5.031^{\mathrm{a}}$ & $5.442^{\mathrm{a}}$ & $-4.102^{\mathrm{a}}$ & Rejected \\
\hline Model - 5: (I, PPI, RIR, PI, TO) & $5.579^{a}$ & $-3.806^{a}$ & $8.574^{\mathrm{a}}$ & $-3.745^{b}$ & Rejected \\
\hline
\end{tabular}

Note: $\mathrm{H}_{0}$ indicates no cointegration. The optimum lag is selected by using the Schwarz Bayesian criterion. Lag is the number of lags, $F_{I I I}$ represents the $\mathrm{F}$ statistic of the model with unrestricted intercept and no trend. $F_{V}$ represents the F-statistic of the model with unrestricted intercept and trend. The $t_{V}$ and $t_{I I I}$ are the $t$ ratios are respectively with and without a deterministic linear trend.

'c' indicates that the statistic lies below the 0.10 lower bound

'b' that it falls within the 0.10 bounds and

a' that it lies above the 0.10 upper bound.

Table-5.4. Long Run Coefficients of the Private Investment Model

\begin{tabular}{|c|c|c|c|c|c|c|}
\hline & & 1 & 2 & 3 & 4 & 5 \\
\hline & Constant & $-5.251^{\mathrm{a}}$ & $-7.016^{\mathrm{a}}$ & $-7.558^{a}$ & $-2.310^{\mathrm{a}}$ & -2.387 \\
\hline & $\operatorname{Ln}(\mathrm{PPI})$ & $1.591^{\mathrm{a}}$ & $2.327^{\mathrm{a}}$ & $1.787^{\mathrm{a}}$ & $1.088^{\mathrm{a}}$ & $1.266^{\mathrm{a}}$ \\
\hline & RIR & 0.0006 & -0.002 & 0.021 & $-0.010^{b}$ & $-0.019^{b}$ \\
\hline & $\operatorname{Ln}(\mathrm{PI})$ & $0.524^{\mathrm{a}}$ & $0.255^{b}$ & $0.813^{a}$ & $0.257^{\mathrm{b}}$ & $1.774^{\mathrm{a}}$ \\
\hline \multicolumn{7}{|l|}{ de jure } \\
\hline & $\operatorname{Ln}(\mathrm{FLI})$ & $0.085^{b}$ & - & - & - & - \\
\hline & Ln(TLI) & - & -0.173 & - & - & - \\
\hline & Ln(K_Open) & - & - & -0.286 & - & - \\
\hline \multicolumn{7}{|l|}{ de facto } \\
\hline & $\operatorname{Ln}(\mathrm{FO})$ & - & - & - & 0.363 & - \\
\hline & $\operatorname{Ln}(\mathrm{TO})$ & - & - & - & - & $-3.162^{\mathrm{a}}$ \\
\hline
\end{tabular}

Note: Ln shows the sign of natural logarithm, PPI stands for per capita real private income, RIR stands for real interest rate, PI stands for real public investment (PI), FLI stands for financial liberalization index, TLI stands for trade liberalization index, K_Open stands for capital account liberalization index, FO stands for financial openness index, TO stands for trade openness (TO).

a indicates $1 \%$ level of significance.

b indicates $5 \%$ level of significance.

c indicates $10 \%$ level of significance.

Table-5.5. Short Run Coefficients of Private Investment Model

\begin{tabular}{|c|c|c|c|c|c|c|}
\hline & & (1) & $(2)$ & (3) & (4) & $(5)$ \\
\hline & Intercept & 0.033 & $0.008^{c}$ & $0.038^{\mathrm{c}}$ & $0.039^{c}$ & 0.014 \\
\hline & $\Delta \operatorname{Ln}(\mathrm{PPI})$ & $0.631^{b}$ & $0.434^{b}$ & $0.543^{\mathrm{a}}$ & $0.607^{a}$ & $0.443^{c}$ \\
\hline & $\Delta \mathrm{RIR}$ & -0.0005 & $-0.007^{c}$ & $-0.005^{c}$ & $-0.011^{b}$ & $-0.002^{c}$ \\
\hline & $\Delta \operatorname{Ln}(\mathrm{PI})$ & $0.302^{\mathrm{b}}$ & $0.303^{c}$ & 0.743 & $0.265^{\mathrm{b}}$ & $0.247^{c}$ \\
\hline \multicolumn{7}{|l|}{ de jure } \\
\hline & $\Delta \operatorname{Ln}(\mathrm{FLI})$ & $0.054^{\mathrm{c}}$ & - & - & - & - \\
\hline & TLI & - & -0.021 & - & - & - \\
\hline & $\Delta \operatorname{Ln}($ K_Open) & - & - & -0.021 & - & - \\
\hline & $\Delta \operatorname{Ln}($ K_Open $(-1))$ & - & - & $0.129^{a}$ & - & - \\
\hline \multicolumn{7}{|l|}{ de facto } \\
\hline & $\Delta \mathrm{Ln}(\mathrm{FOI})$ & - & - & - & $0.118^{\mathrm{a}}$ & - \\
\hline & $\Delta \operatorname{Ln}(\mathrm{TO})$ & - & - & - & - & 0.011 \\
\hline & $\operatorname{ECM}(-1)$ & $-0.869^{a}$ & $-0.339^{b}$ & $-0.453^{a}$ & $-0.915^{a}$ & $-0.451^{c}$ \\
\hline & $\mathrm{R}-$ squared & 0.547 & 0.647 & 0.625 & 0.632 & 0.611 \\
\hline
\end{tabular}

Note: Ln shows the sign of natural logarithm, PPI stands for per capita real private income, RIR stands for real interest rate, PI stands for real public investment (PI), FLI stands for financial liberalization index, TLI stands for trade liberalization index, K Open stands for capital account liberalization index, FOI stands for financial openness index, TO stands for trade openness (TO).

a indicates $1 \%$ level of significance.

$\mathrm{b}$ indicates $5 \%$ level of significance.

c indicates $10 \%$ level of significance. 
Table 5.2 reports the results of $\mathrm{t}$ - and F-statistics for the bounds tests. ${ }^{14}$ In term of the results, the null hypothesis of no co-integration for the private investment equation is rejected at the $10 \%$ level for five models. The long-run coefficient of the private investment model reported in Table 5.4 indicates that private investment is positively related with real per capita private income which is in line with the predictions of the neoclassical model. A $1 \%$ increase in per capita real private income is expected to stimulate private investment by 1.088 to 2.327 percent. The finding that income/output is an important determinant of private investment is consistent with Sakr (1993); Shrestha and Chowdhury (2007) and Ang (2009). The elasticity of real interest rate with respect to private investment is -0.010 to 0.019 statistically significant suggesting little if any, evidence to support real interest rate (user cost of capital) as a useful determinant of private investment in Pakistan.

The public investment is positively related with the private investment which indicates a rise in government investment is associated with an increase in private sector investment. Thus, the current effort made by the Pakistan government to spend on infrastructure development may stimulate, rather than crowd out private capital formation.

The coefficient of financial liberalization index is positively related with private investment, indicating that internal financial reforms (e.g., banking and stock market) stimulate private investment in Pakistan. A $1 \%$ increase in LnFLI increases private investment by $0.0855 \%$. The expansion of banking service such as new banks and more branches which improve access to banking services and lowers the banking transaction cost. This happens due to increased competition and willingness of individuals to save, and thus make more fund available for investment.

As for external financial liberalization, the estimates of the effect of capital account liberalization and financial openness on private investment in Pakistan the coefficients are statistically insignificant. It is plausible that external financial liberalization is less effective in boosting private investment because of the less capital inflow.

We find that trade liberalization is statistically insignificant. The trade openness is negatively related to private investment. A $1 \%$ increase in trade openness reduces private investment by $3.162 \%$. In terms of the theory of trade liberalization, the effect on private investment through higher efficiency in resource allocation may not be achieved due to poor management. Pakistan still is an exporter of raw material due to low investment and income in the export sector.

The short run coefficients presented in Table 5.5 show that the coefficient of real per capital private income is positive and the real interest rate is negatively associated with private investment. In addition, public investment is positively related with the private investment.

Financial liberalization index is found to play a positive role in stimulating private investment in the short- as well as the long run. Based on the results, it appears that internal financial liberalization can help to promote private investment in Pakistan. Trade liberalization and trade openness are statistically insignificant in the short run. Interestingly, the capital account liberalization and financial openness are positively related to the private investment of Pakistan. The better-managed capital account attracts foreign direct investment due to the positive impact of external financial liberalization. The error correction term is negative and significant. It shows the speed of adjustment from short-run disequilibrium to long-run equilibrium. The results indicate that adjustment takes place at a speed of 33.9 to 91.5 percent per year.

\section{Conclusion}

This study empirically examines the impact of financial and trade liberalization on private investment in Pakistan by employing the data from 1971 to 2014. The ARDL results indicate that the cointegration exists among variables and suggest that per capita real private income, public investment, and financial liberalization are positively related to private investment in the long run. These findings are as per our expectation as a percentage of increase in per capita private income is likely to be invested. Moreover, public investment in power, water, roads, etc. through making the infrastructure available give impetus to private investments. Similarly, financial liberalization i.e. liberalization of the banking sector and stock market increase investments by making investment opportunities available to investors. The real interest rate and trade openness are negatively related to private investment in the long run. The positive impact of trade liberalization on private investment emanating from higher efficiency in resource allocation might not have been achieved due to poor management. Pakistan's exports still comprise of large quantities of primary goods and raw material which explains the low investment and income levels in the export sector. The short-run results indicate that capital account liberalization and financial openness are positively associated with private savings.

\section{References}

Abiad, A., E. Detragiache and T. Tressel, 2010. A new database of financial reforms. IMF Staff Papers, 57(2): 281-302. View at Google Scholar View at Publisher

Achy, L., 2005. Financial liberalization, savings, investment, and growth in MENA countries. In Money and Finance in the Middle East: Missed Opportunities or Future Prospects?. Emerald Group Publishing Limited. pp: 67-94.

Acosta, P. and A. Loza, 2005. Short and long-run determinants of private investment in Argentina. Journal of Applied Economics, 8(2): 389406. View at Google Scholar

Akkina, K.R. and M.A. Celebi, 2002. The determinants of private fixed investment and the relationship between public and private capital accumulation in Turkey. Pakistan Development Review, 41(3): 243-254. View at Google Scholar $\mid$ View at Publisher

Ang, J.B., 2009. Private investment and financial sector policies in India and Malaysia. World Development, 37(7): 1261-1273. View at Google Scholar $\mid$ View at Publisher

Ang, J.B. and W.J. McKibbin, 2007. Financial liberalization, financial sector development, and growth: Evidence from Malaysia. Journal of Development Economics, 84(1): 215-233. View at Google Scholar | View at Publisher

Baldwin, R.E., 1989. Measurable dynamic gains from trade. Journal of Political Economy, 100(1): 162-174. View at Google Scholar $\mid$ View at Publisher

Banerjee, A., J. Dolado and R. Mestre, 1998. Error-correction mechanism tests for cointegration in a single-equation framework. Journal of Time Series Analysis, 19(3): 267-283. View at Google Scholar | View at Publisher

Bhagwati, J., 1998. The capital myth: The difference between trade in widgets and dollars. Foreign Affairs, 77(3): 7-12. View at Google Scholar

View at Publisher
Blejer, M.I., and M.S. Khan, 1984. Government policy and private investment in developing countries. Staff Papers, 31(2): 379-403. View at Google Scholar

${ }_{14}$ The Schwarz's Bayesian information criteria (SBC) is used in the lags selection process. 
Chinn, M.D. and H. Ito, 2006. What matters for financial development? Capital controls, institutions, and interactions. Journal of Development Economics, 81(1): 163-192. View at Google Scholar | View at Publisher

Courakis, A.S., 1984. Constraints on bank choices and financial repression in less developed countries. Oxford Bulletin of Economics and Statistics, 46(4): 341-370. View at Google Scholar $\mid$ View at Publisher

Dang, V., 2012. Institutional determinants of investment in transition economies (Working Paper No. 09-33). Retrieved from https://www.brunel.ac.uk/_data/assets/pdf_file/0019/82126/0933.pdf.

Dickey, D.A. and W.A. Fuller, 1979. Distribution of the estimators for autoregressive time series with a unit root. Journal of the American Statistical Association, 74(366a): 427-431. View at Google Scholar | View at Publisher

Engle, R.F. and C.W.J. Granger, 1987. Co-integration and error correction: Representation, estimation, and testing. Econometrica, $55(2)$ : 251-276. View at Google Scholar $\mid$ View at Publisher

Francois, J.F., B.J. McDonald and H. Nordstrom, 1999. Trade liberalization and investment in a multilateral framework. Dynamic Issues in Commercial Policy Analysis: 202-222. View at Google Scholar

Fry, M.J., 1988. Money, interest, and banking in economic development. Baltimore and London: Johns Hopkins University Press.

Greene, J. and D. Villanueva, 1991. Private investment in developing countries: An empirical analysis. Staff Papers, 38(1): 33-58. View at Google Scholar

Haroon, M. and M. Nasr, 2011. Role of private investment in the economic development of Pakistan. International Review of Business Research Paper, 7(1): 420-439. View at Google Scholar

Hellmann, T.F., K.C. Murdock and J.E. Stiglitz, 2000. Liberalization, moral hazard in banking, and prudential regulation: Are capital requirements enough? American Economic Review, 90(1): 147-165. View at Google Scholar $\mid$ View at Publisher

Henry, P.B., 2000. Do stock market liberalization cause investment booms? Journal of Financial Economics, 58(1): 301-334. View at Google Scholar $\mid$ View at Publisher

Hye, Q.M.A. and W.-Y. Lau, 2017. Economic liberalization and economic growth: An empirical analysis of Pakistan. Asian Economic and Financial Review, 7(12): 1256-1302. View at Google Scholar $\mid$ View at Publisher

Jenkins, C., 1998. Determinants of private investment in Zimbabwe. Journal of African Economies, 7(1): 34-61. View at Google Scholar $\mid$ View at Publisher

Johansen, S., 1991. Estimation and hypothesis testing of cointegration vectors in Gaussian vector autoregressive models. Econometrica, 59(6): 1551-1580. View at Google Scholar | View at Publisher

Johansen, S., 1995. A statistical analysis of cointegration for I (2) variables. Econometric Theory, 11(1): 25-59. View at Google Scholar $\mid$ View at Publisher

Jongwanich, J. and A. Kohpaiboon, 2008. Private investment: Trends and determinants in Thailand. World Development, 36(10): 1709-1724. View at Google Scholar | View at Publishe

Jorgenson, D., 1967. The theory of investment behavior. In determinants of investment behavior. NBER: 129-175.

Krueger, A.O., 1978. Foreign trade regimes and economic development: Liberalization attempts and consequences. Lexington, MA: Ballinger Press for NBER.

Lahiri, A., 2001. Growth and equilibrium indeterminacy: The role of capital mobility. Economic Theory, 17(1): 197-208. View at Google Scholar View at Publisher

Lane, P.R. and G.M. Milesi-Ferretti, 2007. The external wealth of nations mark II: Revised and extended estimates of foreign assets and liabilities, 1970-2004. Journal of International Economics, 73(2): 223-250. View at Google Scholar $\mid$ View at Publisher

Levine, R., 2001. International financial liberalization and economic growth. Review of International Economics, 9(4): 688-702. View at Google Scholar $\mid$ View at Publisher

MacKinnon, J.G., 1996. Numerical distribution functions for unit root and cointegration tests. Journal of Applied Econometrics, 11(6): 601618. View at Google Scholar View at Publisher

Majeed, M.T., and S. Khan, 2008. The determinants of private investment and the relationship between public and private investment in Pakistan. NUST Journal of Business and Economics, 1(1): 41-48. View at Google Scholar

Mckinnon, R.I., 1973. Money and capital in economic development. Washington, DC: Brookings Institution.

Narayan, P.K., 2005. The saving and investment nexus for China: Evidence from cointegration tests. Applied Economics, 37(17): 1979-1990. View at Google Scholar | View at Publisher

Pesaran, M.H., Y. Shin and R.J. Smith, 2001. Bounds testing approaches to the analysis of level relationships. Journal of Applied Econometrics, 16(3): 289-326. View at Google Scholar | View at Publisher

Razin, A., E. Sadka and T. Coury, 2002. Trade openness and investment instability (Working Paper No. 8827). National Bureau of Economic Research. Retrieved from http://www.nber.org/papers/w8827.

Rodrik, D., 1998. Who needs capital-account convertibility? Essays in International Finance, 207: 55-65. View at Google Scholar

Saghir, R. and A. Khan, 2012. Determinants of public and private investment an empirical study of Pakistan. International Journal of Business and Social Science, 3(4): 183-188. View at Google Scholar

Sakr, K., 1993. Determinants of private investment in Pakistan (Working Paper No. WP/93/30). Retrieved from International Monetary Fund. Retrieved from http://unpan1.un.org/intradoc/groups/public/documents/apcity/unpan026318.pdf.

Salahuddin, M., R. Islam and S. Salim, 2009. Determinants of investment in Muslim developing countries: An empirical investigation. International Journal of Economics and Management, 3(1): 100-129. View at Google Scholar

Schwarz, A.M., 1992. How effective are directed credit policies in the United States?: A Literature Survey (Work Paper No. WPS1019). World Bank. Retrieved from http://documents.worldbank.org/curated/en/1992/11/699518/effective-directed-credit-policiesunited-states-literature-survey.

Shaw, E.S., 1973. Financial deepening in economic development. New York: Oxford University Press.

Shrestha, M.B. and K. Chowdhury, 2007. Testing financial liberalization hypothesis with ARDL modeling approach. Applied Financial Economics, 17(18): 1529-1540. View at Google Scholar | View at Publisher

Spatafora, M.N., and M.O. Luca, 2012. Capital inflows, financial development, and domestic investment: determinants and inter-relationships (No. 12-120). International Monetary Fund. Retrieved from https://www.imf.org/external/pubs/ft/wp/2012/wp12120.pdf.

Stiglitz, J.E., 1994a. Economic growth revisited. Industrial and Corporate Change, 3(1): 65-110. View at Google Scholar

Stiglitz, J.E., 1994b. The role of the state in financial markets: In M. Bruno and B. Pleskovic (eds), Proceedings of the World Bank Annual Conference on Development Economics, 1993: Supplement to the World Bank Economic Review and the World Bank Research Observer. Washington, DC: World Bank. pp: 19-52.

Stiglitz, J.E., 2000. Capital market liberalization, economic growth, and instability. World Development, 28(6): 1075-1086. View at Google Scholar $\mid$ View at Publisher

Stiglitz, J.E. and A. Weiss, 1981. Credit rationing in markets with imperfect information. American Economic Review, 71(3): 393-410. View at Google Scholar

Sundararajan, V. and S. Thakur, 1980. Public investment, crowding out, and growth: A dynamic model applied to India and Korea. Staff Papers, 27(4): 814-855. View at Google Scholar $\mid$ View at Publisher

Taylor, L., 1983. Structuralist Macroeconomics: Applicable models for the third world. New York: Basic Books.

Van Wijnbergen, S., 1982. Stagflationary effects of monetary stabilization policies: A quantitative analysis of South Korea. Journal of Development Economics, 10(2): 133-169. View at Google Scholar | View at Publisher

Wacziarg, R. and K.H. Welch, 2008. Trade liberalization and growth: New evidence. World Bank Economic Review, 22(2): 187-231. View at Google Scholar | View at Publisher

Zebib, M. and M. Muoghalu, 1997. Dynamic nature of private investment function and its determinants in developing countries. Studies in Economics and Finance, 18(1): 100-1 10. View at Google Scholar | View at Publisher

Asian Online Journal Publishing Group is not responsible or answerable for any loss, damage or liability, etc. caused in relation to/arising out of the use of the content. Any queries should be directed to the corresponding author of the article. 